\title{
Management of trawl by-catch with reference to Visakhapatnam Fishing Harbor: Andhra Pradesh, India
}

\author{
${ }^{1}$ Sudharani P., ${ }^{2}$ Kishan K.P.C., ${ }^{3}$ Ramamohanrao M., ${ }^{4}$ Manjulatha C. \\ ${ }^{1}$ Assistant Professor, Dept. of Biotechnology, GITAM (Deemed to be University), Visakhapatnam-530045, India. \\ ${ }^{2}$ Professor, Dept. of Entrepreneurship, GITAM (Deemed to be University), Visakhapatnam-530045, India. \\ ${ }^{3}$ Professor, Dept. of Entrepreneurship, GITAM (Deemed to be University), Visakhapatnam-530045, India. \\ ${ }^{4}$ Professor \& HOD, Dept. of Zoology, Andhra University, Visakhapatnam-530003, India.
}

\begin{abstract}
:
Trawl fishery is a mixed fishery targeting numerous species including consequential huge amounts of non-targeted species, referred to as low value bycatch/trash fish. The aim of the present study is to analyse the composition of trawl bycatch and its management in view of its proper utilization for aqua feed. Random samples of trash fish were collected fortnightly between March 2019 and February 2020 from single day and multi day trawler landings at Visakhapatnam Fishing Harbour (VFH). The preliminary process of utilizing the landed trash fish at VFH is observed.

The results of the study revealed the presence of 38 dominant species of finfish and shellfish, representing the families, Leiognathidae, Trichiuridae, Mullidae, Clupeidae and Nemipteridae with 29.73\%, $22.5 \%, 18.69 \%, 11.96 \%$ and $10.59 \%$ respectively of 609.991 tons total landing during the study period. The highest landing is $83.362 t$ reported in the month of Feb, 2019 and lowest landing is $32.2 t$ reported in the month of Oct, 2020.

The study concludes that considerable trash fish composition is being landed at VFH, causing the necessity for Entrepreneurs, to pay immediate attention towards the utilization of total trawl bycatch in terms of converting it into feed and supply to aquaculture and poultry industries. Further research will be beneficial for policy makers to address better trawl bycatch management options.
\end{abstract}

Key words: Low value by catch, Trash fish, VFH, Aqua feed, Aquaculture.

\section{Introduction:}

Bycatch and discards are common and recurrent problems faced by fishing industry all over the world. Though few studies concluded on trawl bycatch/trash fish of Visakhapatnam Fishing Harbour (VFH), no concerted effort has been made for proper utilization of it after being landed. The current study conducted between March 2019 and February 2020, is intended to analyse the composition of low value bycatch at VFH and the management of trash fish in view of its proper utilization for the preparation of aqua feed.

Relating to the present study, investigations were done at VFH on; diversity of trawl bycatch ${ }^{[21]}$, mineral and organic composition of bycatch species ${ }^{[22]}$, bycatch and discards ${ }^{[16]}$, trash fish catch of trawl fishery ${ }^{[20]}$ and finfish composition of trawl bycatch ${ }^{[19]}$. Relevantly, trawl bycatch of; landing sites in Jaffna Peninsula $^{[11]}$, Karnataka ${ }^{[3]}$, Tuticorin landing centres ${ }^{[9]}$, Gulf of Carpentaria ${ }^{[13]}$ Veraval $^{[15]}$, two ports in China ${ }^{[7]}$ and diversity of trawl bycatch in India ${ }^{[14]}$ were explored by different researchers.

With respect to the utilization of bycatch, observations were done on assessment of trash fish diet for snakehead aquaculture ${ }^{[8]}$, changing trends in bycatch utilization ${ }^{[4]}$, marketing and utilization of bycatch ${ }^{[1]}$, use of 
low value trash fish from Asia pacific region ${ }^{[17]}$, status of trash fish utilization and fish feed requirements in aquaculture in India $^{[2]}$, need to develop alternative aquaculture feeds from trawl bycatch ${ }^{[12]}$.

\section{Material and methods:}

During the study period, random samples of trash fish were collected fortnightly from single day and multi day trawler landings of VFH (Map 1), that is located on the east coast of India $\left(17^{\circ} 41^{\prime} 44.89^{\prime} \mathrm{N}\right.$ and $83^{\circ} 18^{\prime}$ $\left.9.01^{\prime \prime} \mathrm{E}\right)$ extending $5 \mathrm{~km}$ from the north western arm to the outer harbour and is connecting to open Sea through the entrance channel.

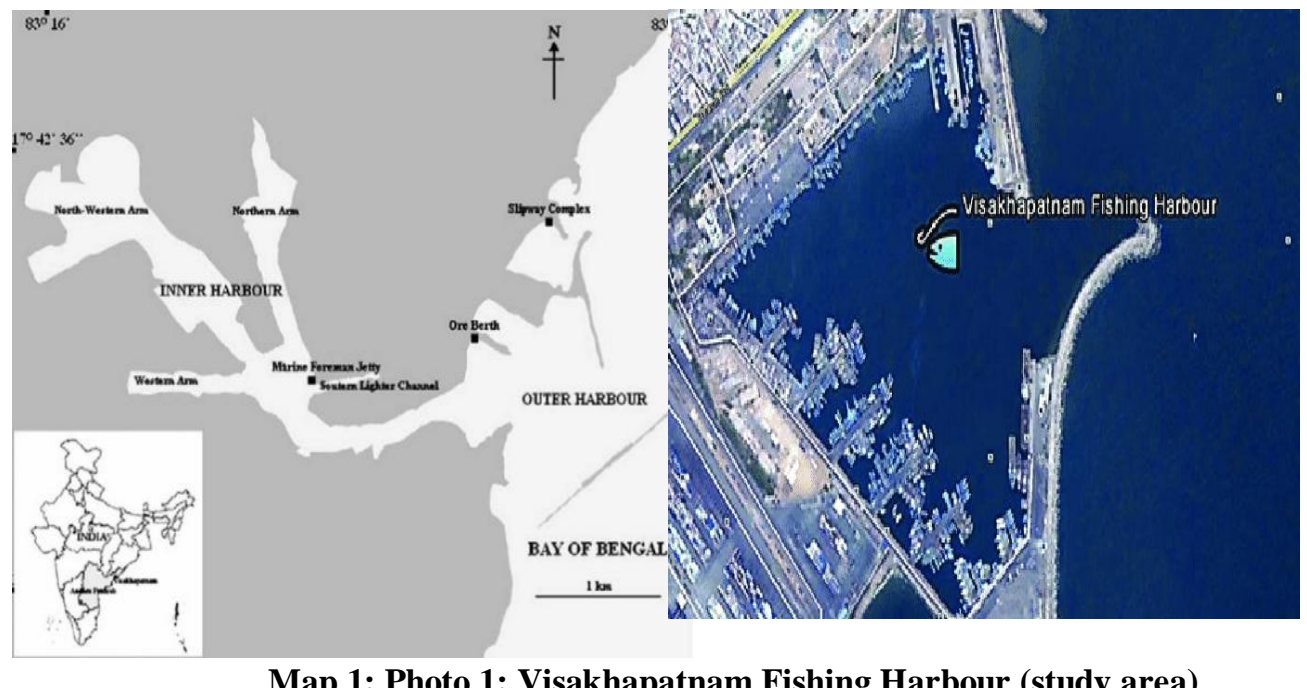

Collected samples were packed in iced polythene bags, brought to the laboratory, washed with tap water, wiped gently and were identified up to their species level using FAO identification sheets ${ }^{[5],[6]}$ and online species identification websites $^{[24]}$. Samples were not available from $16^{\text {th }}$ April 2019 to $15^{\text {th }}$ June 2019 during the study period, as it is the fishing ban period every year and the harbour remains closed.

Data of bycatch landed at VFH by single day as well as multiday trawlers involved in fishing per day was noted on family wise occurrence. The unidentified species from the bycatch and discards into the sea after landing were also recorded. The resultant data gives the total bycatch landed on the given day from all the trawlers. Weekly pooled up data was used to derive monthly estimates besides calculating annual landings (Table 2). Further, after being landed, the fate of trash fish is thoroughly observed during the entire study period with reference to its utilization.

SPSS 16.0 version is used for statistical analysis. Bar graphs were plotted on family wise occurrence of trash fish considering monthly and annual landings at VFH during the study period.

\section{III.Results:}

In the present research, 38 species of fin and shellfishes were identified from single day and multiday trawl bycatch landed at VFH and presented in Table 1.

The major components of trash fish species were 6 species of Leiognathidae, 5 species of Portunidae, 3 species of Clupeidae, 2 species each of Nemipteridae, Mullidae, Priacanthidae, Fistulariidae, Squillidae, 1 species each of Trichiuridae, Anguillidae, Apogonidae, Platycephalidae, Engraulidae, Ogcocephalidae, Engraulidae, Ficidae, Muraenesocidae, Tetradontidae, Muricidae, Harpidae, Sepiidae and Loliginidae. 
Table 1: Composition of low value bycatch collected from the landings at VFH during March 2019 to February 2020

\begin{tabular}{|c|c|}
\hline $\begin{array}{c}\text { Name of the } \\
\text { Family }\end{array}$ & Name of the species \\
\hline \multirow[t]{6}{*}{ Leiognathidae } & Leiognathusequulus(Forsskal, 1775) \\
\hline & Leiognathusberbis(Valenciennes, 1835) \\
\hline & Equulites leuciscus (Gunther, 1860) \\
\hline & Secutorinsidiator(Bloch, 1787) \\
\hline & Eubleekeria splendens (Cuvier, 1829) \\
\hline & Leiognathusbrevirostris(Valenciennes, 1835) \\
\hline \multirow[t]{5}{*}{ Portunidae } & Charybdis(Goniohellenus)hoplites(WoodMason,1877) \\
\hline & Charybdis (Goniohellenus) truncate (Fabricius, 1798) \\
\hline & Portunuspelagicus(Linnaeus, 1758) \\
\hline & Portunushastatus(Linnaeus, 1767) \\
\hline & Charybdis affinis(Dana, 1852) \\
\hline \multirow[t]{3}{*}{ Clupeidae } & Sardinella gibbose (Bleeker, 1849) \\
\hline & Sardinallalongiceps(Valenciennes, 1847) \\
\hline & Sardinella rouxi(Poll, 1953) \\
\hline \multirow[t]{2}{*}{ Nemipteridae } & Nemipterus japonicus (Bloch, 1791) \\
\hline & Nemipterusmesoprion(Bleeker, 1853) \\
\hline \multirow[t]{2}{*}{ Mullidae } & Upeneusvittatus(Forsskal, 1775) \\
\hline & Upeneussulphureus(G. Cuvier, 1829) \\
\hline \multirow[t]{2}{*}{ Priacanthidae } & Priacanthussagittarius(Starnes, 1988) \\
\hline & Priacanthushamrur(Forsskal, 1775) \\
\hline \multirow[t]{2}{*}{ Fistulariidae } & Fistulariacommersonii(Ruppell, 1838) \\
\hline & Fistulariavillosa(Klunzinger,1871) \\
\hline \multirow[t]{2}{*}{ Squillidae } & Squilla oratoria(De Haan,1844) \\
\hline & Squilla mantis (Linnaeus, 1758) \\
\hline Trichiuridae & Trichiuruslepturus(Linnaeus, 1758) \\
\hline Anguillidae & Anguilla bengalensis (J.E.Gray, 1831) \\
\hline Apogonidae & Apogonruber(Lacepede, 1801) \\
\hline Platycephalidae & Platycephalus indicus (Linnaeus, 1758) \\
\hline Engraulidae & Stolephorus indicus (Van Hasselt, 1823) \\
\hline Ogcocephalidae & Halieutaea indica (Annandale \& Jenkins, 1910) \\
\hline Engraulidae & Thryssamalabarica(Bloch, 1795) \\
\hline Ficidae & Ficus gracilis(Sowerby, G.B. 1825) \\
\hline Muraenesocidae & Muraenesoxsps.(McClelland, 1844) \\
\hline Tetradontidae & Tetradonlineatus(Linnaeus, 1758) \\
\hline Muricidae & Drupa (Ricinella) rubusidaeus(Roding, 1798) \\
\hline Harpidae & Harpaconoidalis(Lamarck, 1822) \\
\hline Sepiidae & Sepia inermis(Van Hasselt, 1835) \\
\hline Loligonidae & Loligoduvaucelii(d'Orbigny, 1835) \\
\hline
\end{tabular}


Table 2: Monthly and annual data on family wise occurrence of trash fish (kgs) at VFH during March 2019 to April 2020

\begin{tabular}{|c|c|c|c|c|c|c|c|c|c|c|c|c|c|c|}
\hline $\begin{array}{l}\text { Family/ } \\
\text { Month }\end{array}$ & Mar-19 & Apr-19 & $\begin{array}{l}\text { May- } \\
619\end{array}$ & $\begin{array}{l}\text { June- } \\
19\end{array}$ & July-19 & Aug-19 & Sep-'19 & Oct-'19 & Nov-19 & Dec-19 & Jan-'²0 & Feb-20 & $\begin{array}{c}\text { Annual } \\
\text { Total }\end{array}$ & $\begin{array}{l}\text { Total } \\
\%\end{array}$ \\
\hline Leiognathidae & 21600 & 12457 & 0 & 11967 & 18874 & 19048 & 15756 & 10786 & 12675 & 14670 & 20870 & 22671 & 181374 & 29.73 \\
\hline Trichiuridae & 15647 & 9576 & 0 & 9570 & 12789 & 13768 & 11234 & 8948 & 10985 & 12980 & 14987 & 16780 & 137264 & 22.5 \\
\hline Mullidae & 15670 & 8698 & 0 & 7890 & 9684 & 10989 & 6578 & 4589 & 8679 & 10960 & 13689 & 16570 & 113996 & 18.69 \\
\hline Clupeidae & 7349 & 3738 & 0 & 3009 & 7589 & 7980 & 4689 & 3008 & 5568 & 7999 & 10980 & 11068 & 72977 & 11.96 \\
\hline Nemipteridae & 9890 & 4009 & 0 & 3980 & 5080 & 6100 & 4890 & 3150 & 4589 & 5209 & 7590 & 10110 & 64597 & 10.59 \\
\hline Anguillidae & 789 & 456 & 0 & 370 & 457 & 490 & 658 & 300 & 456 & 670 & 802 & 890 & 6338 & 1.04 \\
\hline Fistulariidae & 548 & 340 & 0 & 298 & 350 & 450 & 290 & 199 & 488 & 401 & 547 & 509 & 4420 & 0.72 \\
\hline Priacanthidae & 198 & 98 & 0 & 86 & 107 & 344 & 104 & 78 & 158 & 236 & 270 & 411 & 2090 & 0.34 \\
\hline Apogonidae & 56 & 24 & 0 & 19 & 34 & 51 & 22 & 11 & 29 & 37 & 55 & 64 & 402 & 0.07 \\
\hline Platycephalidae & 50 & 21 & 0 & 11 & 38 & 24 & 23 & 9 & 19 & 28 & 41 & 30 & 294 & 0.05 \\
\hline Engraulidae & 39 & 11 & 0 & 9 & 12 & 10 & 22 & 14 & 12 & 9 & 3 & 5 & 146 & 0.02 \\
\hline Ogcocephalidae & 24 & 8 & 0 & 7 & 10 & 9 & 12 & 10 & 16 & 7 & 9 & 8 & 120 & 0.02 \\
\hline Engraulidae & 30 & 10 & 0 & 9 & 4 & 13 & 24 & 18 & 29 & 20 & 15 & 19 & 191 & 0.03 \\
\hline Ficidae & 29 & 11 & 0 & 9 & 8 & 11 & 5 & 13 & 10 & 4 & 7 & 10 & 117 & 0.02 \\
\hline Muraenesocidae & 10 & 0 & 0 & 5 & 8 & 10 & 11 & 8 & 2 & 9 & 2 & 10 & 75 & 0.01 \\
\hline Tetradontidae & 14 & 2 & 0 & 9 & 10 & 19 & 17 & 9 & 4 & 8 & 11 & 19 & 122 & 0.02 \\
\hline Muricidae & 19 & 4 & 0 & 5 & 8 & 9 & 10 & 9 & 11 & 10 & 8 & 14 & 107 & 0.02 \\
\hline Harpidae & 20 & 8 & 0 & 3 & 8 & 12 & 27 & 18 & 11 & 29 & 10 & 28 & 174 & 0.03 \\
\hline Portunidae & 508 & 109 & 0 & 177 & 239 & 378 & 289 & 189 & 257 & 380 & 574 & 768 & 3868 & 0.63 \\
\hline Squillidae & 796 & 200 & 0 & 198 & 389 & 466 & 399 & 233 & 499 & 688 & 779 & 958 & 5605 & 0.92 \\
\hline Sepiidae & 767 & 301 & 0 & 178 & 499 & 390 & 245 & 209 & 465 & 679 & 654 & 878 & 5265 & 0.86 \\
\hline Loliginidae & 576 & 189 & 0 & 190 & 288 & 377 & 463 & 112 & 366 & 510 & 546 & 601 & 4218 & 0.69 \\
\hline Unidentified species & 199 & 107 & 0 & 102 & 178 & 191 & 211 & 90 & 189 & 213 & 310 & 327 & 2117 & 0.35 \\
\hline $\begin{array}{l}\text { Discarded into the } \\
\text { Sea }\end{array}$ & 462 & 178 & 0 & 112 & 305 & 418 & 506 & 190 & 317 & 478 & 534 & 614 & 4114 & 0.67 \\
\hline Monthly Total & 75290 & 40555 & 0 & 38213 & 56968 & 61557 & 46485 & 32200 & 45834 & 56234 & 73293 & 83362 & 609991 & 100 \\
\hline Total \% & 12.34 & 6.65 & 0 & 6.26 & 9.34 & 10.09 & 7.62 & 5.28 & 7.51 & 9.22 & 12.02 & 13.67 & 100 & ------ \\
\hline
\end{tabular}


The annual landing of trash fish at VFH was 609.991 tons (Table 2) during the study period with the highest composition of the family Leiognathidae (181.374 t), followed by Trichiuridae (137.264 t) and Mullidae (113.996 t) representing $29.73 \%, 22.5 \%$ and $18.69 \%$ respectively. There is a little fluctuation in the monthly landing of trash fish (Table 2, Fig. 1) with highest landing (83.362 $\mathrm{t}$ and 13.67\%) in Feb- 2020 and the lowest landing (32.2 $\mathrm{t}$ and 5.28\%) in Oct- 2019. Out of the species of 22 families reported in the present research, Leiognathidae, Trichiuridae and Mullidae are dominating during every month of the study period. Members of Clupeidae and Nemipteridae were less fluctuating whereas those of Anguillidae are stable. Even though the members of the remaining families reported were scanty, they were existing in the samples throughout the study period (Table 2, Fig. 2). Moreover, the unidentified species from the bycatch and discards into the sea after landing, out of the entire study period were $2.117 \mathrm{t} \& 0.35 \%$ and $2.114 \mathrm{t} \& 0.67 \%$ respectively.

As the harbour will be closed during fishing ban, the landing of trash fish is comparatively low in the corresponding two months (April \& June) of the study period. No fishing during May'19.

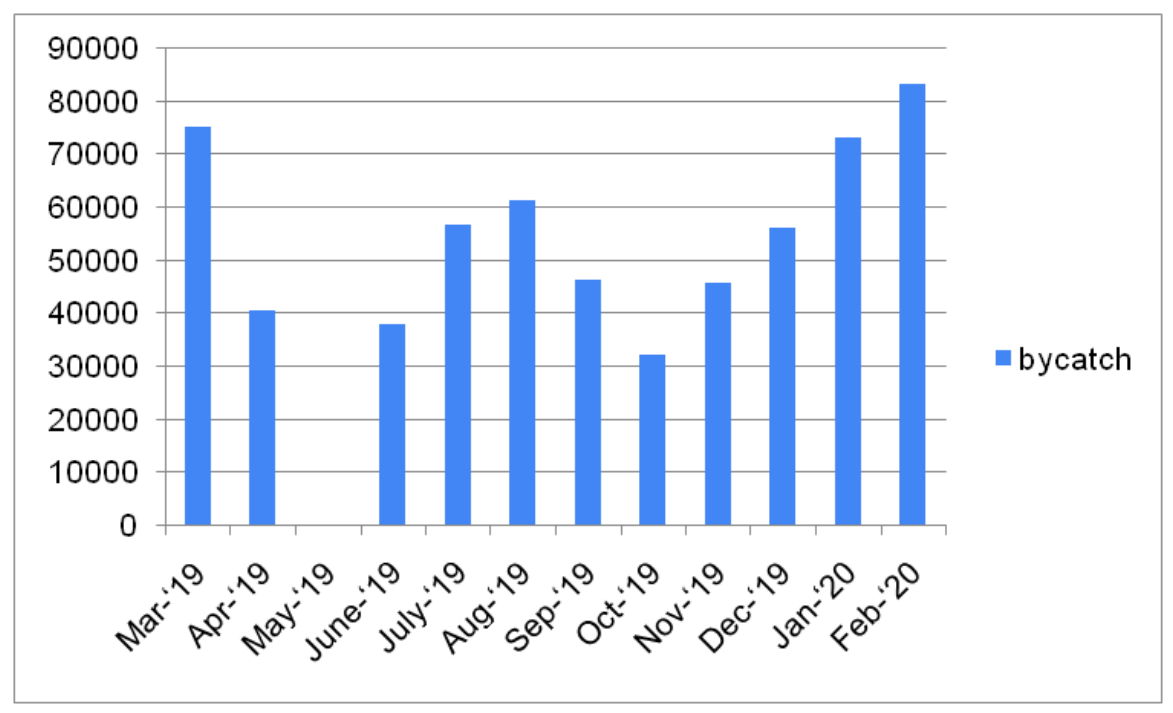

Fig. 1: Monthly data of trash fish (kgs) at VFH during March 2019 to February 2020

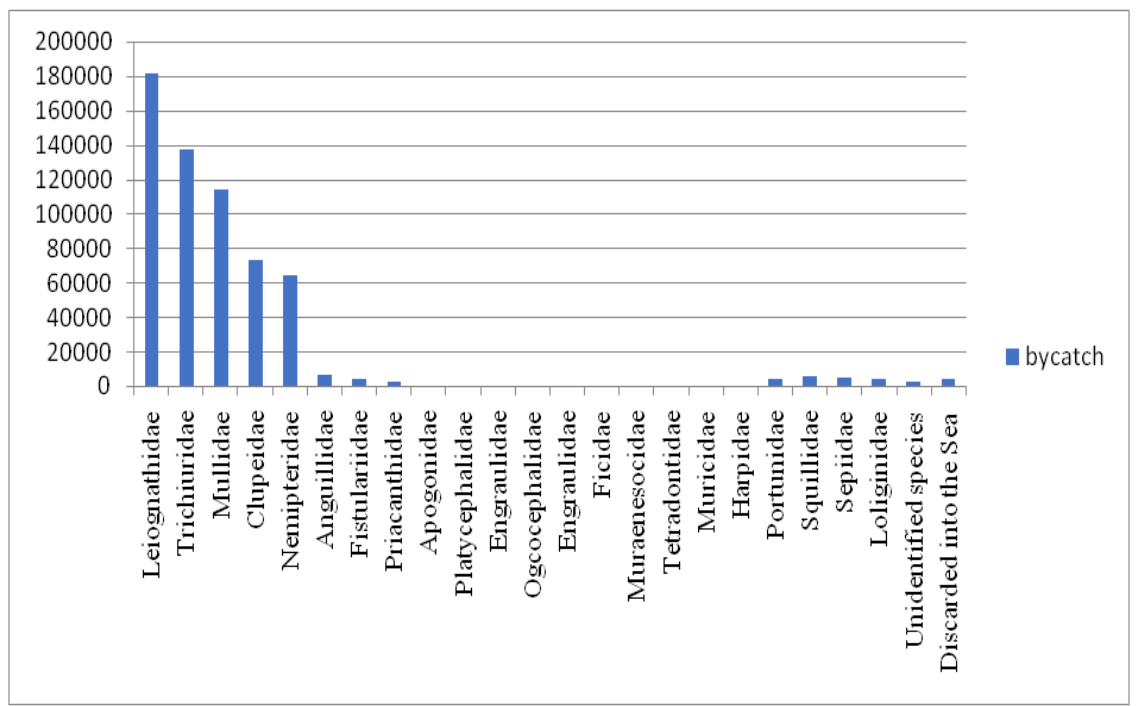

Fig. 2: Annual data on family wise occurrence of trash fish (kgs) at VFH during March 2019 to February 2020 

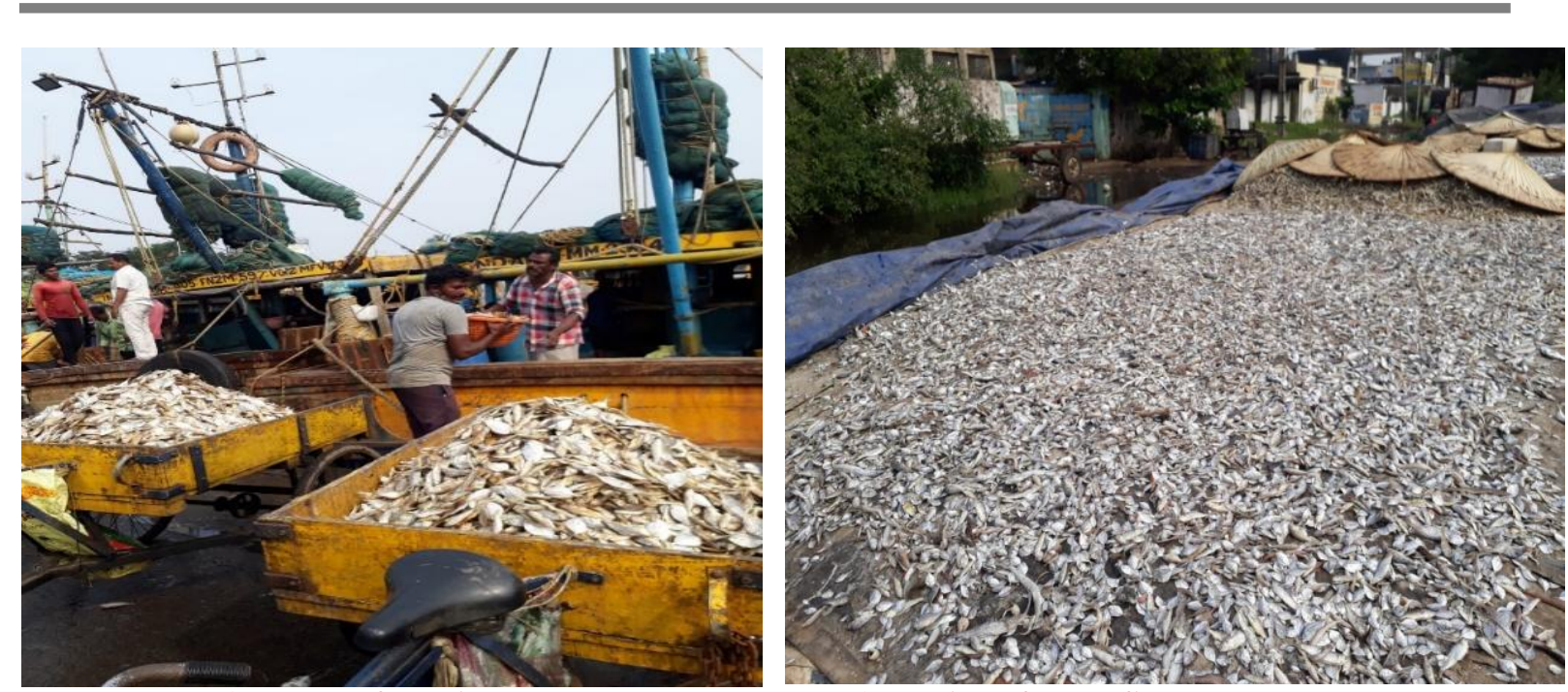

Plate 1: Heaps of landing low value bycatch Plate 2: Drying of trash fish at the study area

These commercially unimportant fish, landed from the trawlers were heaped (Plate 1) in pulling carts. It was observed that, these heaps were subjected for Sun dry with or without salt at poor hygienic conditions (Plate 2), after the transport and trade of the entire commercially important catch was done for the day. As there was limited space for drying, when it was filled, the remaining bycatch was being discarded into the Sea (Table 2) as there was no other option.

After 2 or 3 days of drying, the bycatch was sent to aqua ponds and poultry farms in dry or sometimes in wet state, if it was raining. The leftovers after being sent to aqua and poultry industries, were also being discarded into the Sea (Table 2).

\section{IV.Discussion:}

For several decades, certain categories of fishes had little economic value because of their small size, poor quality or limited appeal to consumers. The so-called trash fish/bycatch are rapidly gaining favour day by day, constituting $40 \%$ of the total marine fish landings ${ }^{[23]}$. These bycatch after landing is subjected to auction and is Sun dried for few hours or days by mixing with minimum quantity of salt, which will be used for aqua feed $^{[18]}$.

Different number of trash fish species were reported from different landing stations by different researchers at different periods. 228 species belonging to 68 families reported previously from the present study area $^{[19]}$ reveals the concept of trash fish landings at VFH. While 38 species belonging to 22 families were reported in the present study, 103 and 42 species of different trash fish were recorded in Tuiticorin fishing harbour in two different studies ${ }^{[9],[10]}$, Veraval ${ }^{[15]}$ reported 87 species of trash fish belonging to 42 families, whereas 9 species of trash fish were reported from Mandapam and Palk Bay region ${ }^{[9]}$. In all these studies, Leiognathidae species are the most abundant which was in agreement with the present study. The gulf of Carpentaria $^{[13]}$ reported 88 species belonging to 12 families, where Catfish (Arius sps.) were by far the most numerous bycatches, differing from the present study.

The trash fish of VFH were found to be rich, especially for the presence of abundant calcium in seasonal bycatch during November and December ${ }^{[22]}$. More than $15 \%$ of organic constituents such as proteins, carbohydrates and lipids were reported in Upeneusvittatus, Trichiuruslepturus and Leiognathusequulusamong bycatch at $\mathrm{VFH}^{[22]}$. The nutritional composition of bycatch at Tuticorin coast ${ }^{[10]}$ also reported to have more than $15 \%$ of the proximate composition. 
Thus, this highly nutrient marine trash fish was used to prepare aquaculture grade Peruvian fishmeal ${ }^{[12]}$ and the trash fish has the potential to be used as a nutrient ingredient for artificial feed formulation in livestock farming ${ }^{[11]}$. These studies disclose that the trash fish may be well utilized as nutrient diet for aqua and poultry animals. Lacking economic value but rich in nutritive status, the trash fish are not utilized properly, but discarded as waste ${ }^{[2]}$. All these reports are in support of the current concept of appropriate maintenance of bycatch for the purpose of aqua feed formulations.

Further, recognising the potential effects of declines in the marine capture fisheries, many governments have turned to aquaculture as a means to increase fish supply. In that connection, the bycatch once discarded by the trawlers are now brought to the shore and sold to increase the revenue ${ }^{[1]}$.Thus, there is an increased landing of trash fish as there is an augmented demand for fishmeal ${ }^{[4]}$. Moreover, with the development of marine cage culture of grouper, lobster, etc.and the expansion of freshwater culture of river catfish in cages, ponds and pens ${ }^{[17]}$ there has been a dramatic raise of trash fish usage in aquaculture.

Recent studies also indicated that the landing and utilization of low value bycatch has increased over the period of time ${ }^{[4]}$. The estimated landing of low value bycatch in trawl fisheries increased from $14 \%$ to $25 \%$ along the coast of India ${ }^{[4]}$, while that at VFH showed a steady increase ${ }^{[4]}$ from $2 \%$ to $21 \%$. At Mangalore fisheries harbour the low value bycatch landing increased ${ }^{[3]}$ from $3 \%$ to $17 \%$ and it was over $60 \%$ in two ports of China ${ }^{[7]}$. The fisher folk are not much aware about the species composition of fishes but, the trash fish are dried and sent to aqua farms.

The need of the present research is further prioritised by the report given during snakehead aquaculture study in Vietnam ${ }^{[8]}$, which has noticed the presence of volatile base nitrogen, that may be indicating poor maintenance of marine trash fish. In the present study, the bycatch landed from both single day and multi day trawlers were left heaped in pulling carts (Plate 1) and subjected to dry after a longer interval of landing. There may be more chances of spoilage before being dried and transported to aqua and poultry farms too. Keeping in view it's shelf-life period and nutritive status as well, the bycatch may be maintained enough since landing at the harbour.

\section{Conclusion:}

The present information regarding the trash fish of VFH would assist the researchers to get better understanding of this nutrient rich resource. In conservation point of view, tons of trash fish have been misused every day in the present study region. So immediate attention is needed, to carry out its utilization with the help of an action plan by the policy makers for conserving this valuable resource.

Based on research reports of the nutrient value of the bycatch, it may be suggested that the processing units may be established at the vicinity of landing area itself, so that without losing the nutrient value, the resource may be converted as feed for culture fisheries and poultry farms. The formulated feeds may be readily available to aquafarmers in required form corresponding to the growth levels of the species in the pond.

The present concept may become a new platform, where the trawl bycatch may be well managed for the production of aqua feed avoiding discards into the Sea, which may be ecofriendly too. The entire system needs to be maintained in-parallel with that of commercially important species by the involvement of effective Entrepreneurs, intern generating employment. Further research may help to develop a protocol through which the total trawl bycatch at VFH may be competently utilized and converted as feed for aquaculture and poultry industries. 


\section{VI.References:}

[1] Aswathi, N., R. Sathyadhas, R. Narayana Kumar and Shyam, S. Salim. (2012). Marketing and utilization of marine bycatch: problems and prospects. J. Fish. Econ. Dev. Vol. XII (2): 1-8.

[2] Chandrapal, G. D. 2005. Status of trash fish utilization and fish feed requirements in aquaculture-India. Paper presented at the regional workshop on low value and trash fish in the Asia-Pacific region. Hanoi, Vietnam 7-9 June 2005.

[3] Dineshbabu A.P, Sujitha Thomas and E. V., Radhakrishnan. (2012). Spatio- temporal analysis and impact assessment of trawl bycatch of Karnataka to suggest operation based fishery management options. Indian J. Fish. Vol. 59(2): 27-38.

[4] Dineshbabu A.P., et al., (2014). An appraisal of trawl fisheries of India with special reference on the changing trends in bycatch utilization.J. Mar. Biol. Ass. India, Vol. 55 (2): 69-78.

[5] FAO species identification sheets for fishery purposes. Western Indian Ocean (Fishing Area 51). FAO Fisheries Department Rome, 1(1984) 233.

[6] FAO. The state of world fisheries and aquaculture. FAO Fisheries and Aquaculture Department, Food and Agriculture Organization of the United Nations, Rome, 2010, 197.

[7] Grainger, R. Xie, Yingliang. Li, Shegfa\& Guo, Zhijie. 2005. Production and utilization of trash fish in selected ports. Paper presented at the APFIC Regional Workshop on Low Value and Trash Fish in the Asia-Pacific Region. Hanoi, Viet Nam, 7-9 June 2005.

[8] Hien, Thanh; Dinh, Tran; Bengtson, David. 2015. Assessment of the Trash-fish Diet for Snakehead Aquaculture in Vietnam: Species Composition and Chemical Characterisation. Asian Fisheries Sciences. Vol. 28: 165-173.

[9] Immaculate jeyasanta K. and Jamila Patterson (2017). Survey on Landing of trash fishes in the major fish landing centers of Tuticorin, South east coast of India. Indian Journal of Geo Marine Sciences, Vol. 46(5): 1022-1043.

[10] Immaculate jeyasanta K. and Jamila Patterson (2014). Nutritive Evaluation of Trash fish in Tuticorin (India). World Journal of Fish and Marine Sciences, Vol. 6(3): 275-288.

[11] Kasthuri S, DuglasSathees and Wijenayake WMHK (2021). Proximate composition analysis of trash fish from the selected landing sites of Jaffna district, Sri Lanka. International Journal of Fisheries and Aquatic Studies. Vol 9(1): 214-216.

[12] Kevin WC, Rimmer MA. The future of feeds and feeding of marine fin fish in the Asia-Pacific region: the need to develop alternative aquaculture feeds. Regional workshop on low value and bycatch in the Asia-pacific region, CSIRO Marine Research. 2005; 1:11-15.

[13] Mark A. Grubert (2019). Catch, discard and bycatch rates in the Western Gulf of Carpentaria Mud Crab Fishery: summary for 2017 and 2018. Northern Territory Naturalist, Vol.29: 88-94.

[14] Nenavath Rajendra Naik. (2019). Diversity of trawl catch in India. ICAR-CIFT, Kochi: 231-238.

[15] Putra Pravin T. and Manohardoss R.C. (1996). Constituents of low value trawl bycatch caught of Veraval. Fish Technol. Vol. 33 (2): 121-123.

[16] Rao, G.S. (1998). Bycatch discards of trawlers of Visakhapatnam In: Advances and priorities in fisheries Technology, Society of fisheries technologists, India: Cochin, 501-505.

[17] Simon Funge Smith, Erick Lindebo and Derek Staples. (2005). Asian Fisheries today-The production and use of low value trash fish from marine fisheries of the Asia Pacific region, Asia-Pacific fishery commission, Food and Agriculture Organization of the United Nations, RAP Publication 16, 38p.

[18] Sudharani P. (2015). Sea Food Landings and Utilization in Andhra Pradesh: India, with Reference to Visakhapatnam Fishing Harbour- A Survey. International Journal of Chem Tech Research. Vol. 7(5): 2408-2412.

[19] Sujatha, K. (1995). Finfish constituents of trawl by-catch off Visakhapatnam. Fish.Technol. 32(1): 56-60.

[20] Sujatha K. (1996). Trash fish catch of the trawl fishery of the Visakhapatnam, J. Aquat. Biol. Vol. 11: 17-23.

[21] T. Sasikala, Manjulatha C. and D.V.S.N. Raju. (2020). Diversity of by catch at Visakhapatnam fishing harbor. International Journal of Fauna and Biological Studies. Vol. 7(1): 118-123.

[22] T. Sasikala, Manjulatha C. and D.V.S.N. Raju. (2020). Analysis of mineral composition in by catch species from Visakhapatnam Fishing Harbor. International Journal of Scientific Research. Vol.9(3): 28-30.

[23] Velayutham P. and Ramadhas V. (2003). Utilization of trash fish for fish sauce, Proc. National seminar on marine biodiversity as a source of food medicine. (SDMRI research publication) 3: 154-156.

[24] Species identification websites: www.fishbase.org, www.cephbase.org, www.shellmuseum.org and www.seashells.org 